\title{
LOGICAL AND EXPERIMENTAL DESIGN FOR PHENOL DEGRADATION USING IMMOBILIZED ACINETOBACTER SP. CULTURE
}

\author{
AMro A. AMARA ${ }^{1,2}$ AND SoHEIr. R. SALEM ${ }^{3}$ \\ ${ }^{1}$ Pharmaceutics Department, Faculty of Pharmacy, King Saud University, Riyadh, Kingdom of \\ Saudi Arabia. \\ ${ }^{2}$ Protein Research Department, Genetic Engineering and Biotechnology Research Institute, \\ Mubarak City for Scientific Research and Technology Applications. Alexandria, Egypt. \\ ${ }^{3}$ Faculty of Education, Biological and Geological Science Department, Alexandria University, \\ Alexandria, Egypt.
}

Email :amroamara@web.de

\begin{abstract}
Phenol and phenolic compounds cause severe pollutant to the nature. Phenol degradation using microbes has been attracted the attention of many researchers. In this study Plackett-Burman design has been used to map and optimize the points affect in the degradation process. Nine variables include $\mathrm{pH}\left(\mathrm{X}_{1}\right),{ }^{\circ} \mathrm{C}\left(\mathrm{X}_{2}\right)$, glucose $\left(\mathrm{X}_{3}\right)$, yeast extract $\left(\mathrm{X}_{4}\right)$, meat extract $\left(\mathrm{X}_{5}\right), \mathrm{NH}_{4} \mathrm{NO}_{3}\left(\mathrm{X}_{6}\right), \mathrm{K}$-salt $\left(\mathrm{X}_{7}\right), \mathrm{Mg}$-salt $\left(\mathrm{X}_{8}\right)$ and trace elements (X9) as a media constituents are optimized during the phenol degradation process using immobilized Acinetobacter sp. According to Plackett-Burman design experiments the maximum degradation rate was $31.25 \mathrm{mg} / \mathrm{l} / \mathrm{h}$. Logical and statistical analysis of the data lead to select $\mathrm{pH}$, Temperature and Meat extract as the most important three factors affecting on the phenol degradation rate. These three variables have been used in Box-Behnken experimental design, which result in degradation rate equal to $35.7 \mathrm{mg} / \mathrm{L} / \mathrm{hr}$. Microsoft Excel 2002 solver tool was used to optimize the model created from Box-Behnken. The calculated degradation rate was $37.30 \mathrm{mg} / \mathrm{l} / \mathrm{hr}$ while the experimental degradation rate was $38.45 \mathrm{mg} / \mathrm{L} / \mathrm{hr}$, which prove the model accuracy. The use of logical analyses of the data covers the limitation of the statistical methods in selecting the correct variables. We recommended using logical and statistical data analysis for optimization the phenol degradation rate and other related processes.
\end{abstract}

KEYWORDS: Plackett-Burman, Box-Behnken, solver, phenol, degradation, optimization, Acinetobacter sp.

\section{INTRODUCTION}

Phenol is a monoaromatic compound produced naturally or chemically [1]. Phenolic compounds found in polluted water resources, industrial effluents of many applications like winedistillery, olive oil extraction, green olive debittering, cork preparation, wood debarking, detoxification of coffee husk etc., and land filled run off wastes [2-7]. Many strategies have been developed for controlling phenol and preventing it from causing harmful effect on Nature [8-10]. Microbes are able to utilize phenolic compounds as a carbon source [11]. Experimental design is a versatile tool for optimization different parameters and conditions [11, 12]. Plackett-Burman [11] and Box-Behnken [13] design 
were used in optimization of the environmental and nutritional condition of the phenol degradation process and the results analyzed statistically using different statistical methods. Logical interpretation of the statistical analysis as well as the crude data proved useful for selecting the most effective variables. The results of the optimization studies obtained from this study proved to be promising.

\section{MATERIALS AND METHODS}

\subsection{Microorganism}

Microbial strain used in this study was isolated from soil and characterized using standard criteria and identified as Acinetobacter sp.

\subsection{Immobilization Technique}

Two-gram agar and $0.75 \mathrm{~g}$ sodium alginate were dissolved in $80 \mathrm{~mL}$ water and stirred well before sterilization. After sterilization, $20 \mathrm{~mL}$ cell suspension was added to the mixture. The mixture ( $3 \mathrm{mg}$ dry weight cells/ml gel) was aseptically extruded drop-wise through a needle into a cold solution of $2 \% \mathrm{CaCl}_{2}$. The beads were transferred to a sterile phosphate buffer solution $\left(1.46 \% \mathrm{~K}_{2} \mathrm{HPO}_{4}\right.$ and $\left.0.22 \% \mathrm{KH}_{2} \mathrm{PO}_{4}\right)$ for $2 \mathrm{~h}$. The beads were then washed and transferred to the Mineral medium containing $0.5 \mathrm{~g} / \mathrm{L}$ phenol. Glucose, yeast extract and meat extract were prepared as stock solution and sterilized using bacterial membrane filter $(0.22 \mu \mathrm{m})$ and added with the quantities as described in Table 1, 2 and 6 .

\subsection{Media Content (g/L)}

$\mathrm{NH}_{4} \mathrm{NO}_{3}, 1.5 ; \mathrm{MgSO}_{4} .7 \mathrm{H}_{2} \mathrm{O}, 0.5 ; \mathrm{K}_{2} \mathrm{HPO}_{4}, 1.0 ; \mathrm{KH}_{2} \mathrm{PO}_{4} 0.5 ; \mathrm{NaCl}, 0.5 ; \mathrm{CaCl}_{2}, 0.02 ;(0-4$ $\mathrm{ml}), \mathrm{pH}$ was adjusted as desired. After autoclaving at $121^{\circ} \mathrm{C}$ for $20 \mathrm{~min}$, trace elements solution was then added [14].

\subsection{Trace Element Solution $(\mathrm{g} / \mathrm{L})$}

$\mathrm{FeSO}_{4} .7 \mathrm{H}_{2} \mathrm{O}, 5 \mathrm{~g} ; \mathrm{H}_{3} \mathrm{BO}_{4}, 25 \mathrm{mg} ; \mathrm{CuSO}_{4} .5 \mathrm{H}_{2} \mathrm{O}, 5 \mathrm{mg} ; \mathrm{KI}, 5 \mathrm{mg} ; \mathrm{CoSO}_{4} .7 \mathrm{H}_{2} \mathrm{O}, 0.3 \mathrm{~g}$; $\mathrm{MnSO}_{4} .4 \mathrm{H}_{2} \mathrm{O}, 3 \mathrm{~g} ; \mathrm{ZnSO}_{4} .7 \mathrm{H}_{2} \mathrm{O}, 5 \mathrm{~g} ; \mathrm{NaMoO}_{4} .7 \mathrm{H}_{2} \mathrm{O}, 12 \mathrm{mg}$. The solution was filter sterilized with a $0.22 \mu \mathrm{m}$ membrane filter.

\subsection{Fermentation Procedures}

Phenol degradation was conducted using $250 \mathrm{~mL}$ Erlenmeyer-flask containing $100 \mathrm{~mL}$ media and $20 \mathrm{~mL}$ gel (immobilized cells), at a shaking rate of $180 \mathrm{rpm}$. The media composition, $\mathrm{pH}$, and temperature were changed when running both of Plackett-Burman and Box-Behnken design as described in Table 2 and 6.

\subsection{Phenol Assay}

The method described by Korenman et al. (1998) was used to determine the phenol degradation rate as $\mathrm{mg} / \mathrm{L} / \mathrm{hr}[15]$. 


\subsection{Experimental Designs}

\section{A. Media Constituents Effect}

Two experiments with or without the media constituents as described above, in presence of $0.5 \mathrm{~g} / \mathrm{L}$ phenol, were conducted. One experiment was conducted using all the above described media constituents while the other contain none of them. The phenol degradation rate was determined as $\mathrm{mg} / \mathrm{L} / \mathrm{hr}$.

\section{B. Plackett-Burman}

Plackett-Burman design was used for screening the effect of nine variables include $\mathrm{pH}$ $\left(\mathrm{X}_{1}\right)$, temperature $\left(\mathrm{X}_{2}\right)$, glucose $\left(\mathrm{X}_{3}\right)$, yeast extract $\left(\mathrm{X}_{4}\right)$, meat extract $\left(\mathrm{X}_{5}\right), \mathrm{NH}_{4} \mathrm{NO}_{3}\left(\mathrm{X}_{6}\right)$, $\mathrm{K}$-salt $\left(\mathrm{X}_{7}\right), \mathrm{Mg}$-salt $\left(\mathrm{X}_{8}\right)$ and trace elements $\left(\mathrm{X}_{9}\right)$. The experimental design was created following the design described by Plackett and Burman [12] where sixteen experiments were created to analyze the effect of the different variables on the phenol degradation rate as summarized in Table 1.

\section{Multiple Regression Analysis of the Plackett-Burman Experiments}

The results of the Plackett-Burman experiments were analyzed by multiple regression analysis using Microsoft Excel 2002 as described in details by Abdel-Fattah and Olama [16]. From the statistical analysis of the data as in Table 2, which has been tabulated in Table 3, the variables whose confidence levels $\geq$ than $90 \%$ were considered to be significant. Variables with confidence level between $90 \%$ and $70 \%$ were considered as being effective [17].

Table 1: Phenol degradation rate with or without media constituents

\begin{tabular}{|c|c|c|c|c|c|c|c|c|c|c|c|}
\hline \multicolumn{2}{|c|}{$\begin{array}{l}\text { Expt. } \\
\text { No. }\end{array}$} & $\mathrm{pH}$ & ${ }^{\circ} \mathrm{C}$ & $\begin{array}{c}\text { Glucose } \\
\mathrm{g} / \mathrm{L}\end{array}$ & $\begin{array}{l}\text { Yeast } \\
\text { extract } \\
\mathrm{g} / \mathrm{L}\end{array}$ & $\begin{array}{c}\text { Meat } \\
\text { extract } \\
\mathrm{g} / \mathrm{L}\end{array}$ & $\begin{array}{c}\mathrm{NH}_{4} \mathrm{NO}_{3} \\
\mathrm{~g} / \mathrm{L}\end{array}$ & $\begin{array}{c}\text { K salt } \\
\mathrm{g} / \mathrm{L}\end{array}$ & $\begin{array}{c}\mathrm{Mg} \\
\text { salt } \\
\mathrm{g} / 1\end{array}$ & $\begin{array}{c}\text { Trace } \\
\text { element } \\
\mathrm{ml} / 100\end{array}$ & $\begin{array}{l}\text { Phenol } \\
\text { degradation } \\
\text { rate } \\
\\
\mathrm{mo} / \mathrm{L} / \mathrm{h}\end{array}$ \\
\hline+ & 1 & $+1(8)$ & $+1(40$ & $+1(15)$ & $+1(4)$ & $+1(4)$ & $+1(1.5)$ & $+1(1.5)$ & $+1(0.5$ & $+1(4)$ & 0 \\
\hline- & 18 & $-1(4)$ & $-1(20$ & $-1(0)$ & $-1(0)$ & $-1(0)$ & $-1(0)$ & $-1(0)$ & $-1(0)$ & $-1(0)$ & 13.6 \\
\hline
\end{tabular}


Table 2: Plackett-Burman experiments.

\begin{tabular}{|c|c|c|c|c|c|c|c|c|c|c|c|}
\hline \multicolumn{2}{|c|}{$\begin{array}{c}\text { Expt. } \\
\text { No. }\end{array}$} & \multirow{2}{*}{$\begin{array}{l}\mathrm{pH} \\
\\
+1 \\
(8) \\
\end{array}$} & \multirow{2}{*}{$\begin{array}{c}{ }^{\circ} \mathrm{C} \\
\\
-1 \\
(20) \\
\end{array}$} & \multirow{2}{*}{$\begin{array}{c}\begin{array}{c}\text { Glucose } \\
\mathrm{g} / \mathrm{L}\end{array} \\
+1(15)\end{array}$} & \multirow{2}{*}{$\begin{array}{c}\begin{array}{c}\text { Yeast } \\
\text { extract } \\
\mathrm{g} / \mathrm{L}\end{array} \\
+1(4)\end{array}$} & \multirow{2}{*}{$\begin{array}{c}\begin{array}{c}\text { Meat } \\
\text { extract } \\
\mathrm{g} / \mathrm{L}\end{array} \\
-1(0)\end{array}$} & \multirow{2}{*}{$\begin{array}{c}\mathrm{NH}_{4} \mathrm{NO}_{3} \\
\mathrm{~g} / \mathrm{L}\end{array}$} & \multirow{2}{*}{$\begin{array}{c}\text { K salt g/L } \\
+1(1.5)\end{array}$} & \multirow{2}{*}{$\begin{array}{c}\underset{\mathrm{Mg} \text { salt }}{\mathrm{g} / 1} \\
+1(0.5)\end{array}$} & \multirow{2}{*}{$\begin{array}{c}\begin{array}{c}\text { Trace } \\
\text { element } \\
\mathrm{ml} / 100 \mathrm{ml}\end{array} \\
-1(0)\end{array}$} & \multirow{2}{*}{$\begin{array}{c}\begin{array}{c}\text { Phenol } \\
\text { degradation } \\
\text { rate } \\
\mathrm{mg} / \mathrm{L} / \mathrm{hr}\end{array} \\
0\end{array}$} \\
\hline \multirow{16}{*}{ 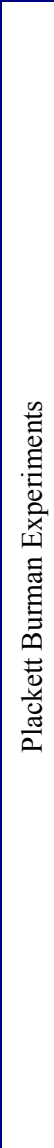 } & 1 & & & & & & & & & & \\
\hline & 2 & $\begin{array}{l}+1 \\
(8)\end{array}$ & $\begin{array}{c}+1 \\
(40)\end{array}$ & $-1(0)$ & $+1(4)$ & $+1(4)$ & $-1(0)$ & $+1(1.5)$ & $+1(0.5)$ & $+1(4)$ & 31.25 \\
\hline & 3 & $-1(4)$ & $\begin{array}{c}+1 \\
(40) \\
\end{array}$ & $+1(15)$ & $-1(0)$ & $+1(4)$ & $+1(1.5)$ & $-1(0)$ & $+1(0.5)$ & $+1(4)$ & 0 \\
\hline & 4 & $-1(4)$ & $\begin{array}{c}-1 \\
(20)\end{array}$ & $+1(15)$ & $+1(4)$ & $-1(0)$ & $+1(1.5)$ & $+1(1.5)$ & $-1(0)$ & $+1(4)$ & 0 \\
\hline & 5 & $-1(4)$ & $\begin{array}{c}-1 \\
(20)\end{array}$ & $-1(0)$ & $+1(4)$ & $+1(4)$ & $-1(0)$ & $+1(1.5)$ & $+1(0.5)$ & $-1(0)$ & 8.62 \\
\hline & 6 & $-1(4)$ & $\begin{array}{c}-1 \\
(20)\end{array}$ & $-1(0)$ & $-1(0)$ & $+1(4)$ & $+1(1.5)$ & $-1(0)$ & $+1(0.5)$ & $+1(4)$ & 17.86 \\
\hline & 7 & $\begin{array}{l}+1 \\
(8) \\
\end{array}$ & $\begin{array}{c}-1 \\
(20)\end{array}$ & $-1(0)$ & $-1(0)$ & $-1(0)$ & $+1(1.5)$ & $+1(1.5)$ & $-1(0)$ & $+1(4)$ & 15.63 \\
\hline & 8 & $-1(4)$ & $\begin{array}{c}+1 \\
(40)\end{array}$ & $-1(0)$ & $-1(0)$ & $-1(0)$ & $-1(0)$ & $+1(1.5)$ & $+1(0.5)$ & $-1(0)$ & 17.86 \\
\hline & 9 & $-1(4)$ & $\begin{array}{c}-1 \\
(20) \\
\end{array}$ & $+1(15)$ & $-1(0)$ & $-1(0)$ & $-1(0)$ & $-1(0)$ & $+1(0.5)$ & $+1(4)$ & 0 \\
\hline & 10 & $\begin{array}{l}+1 \\
(8)\end{array}$ & $\begin{array}{c}-1 \\
(20)\end{array}$ & $-1(0)$ & $+1(4)$ & $-1(0)$ & $-1(0)$ & $-1(0)$ & $-1(0)$ & $+1(4)$ & 22.73 \\
\hline & 11 & $\begin{array}{l}+1 \\
(8)\end{array}$ & $\begin{array}{c}+1 \\
(40)\end{array}$ & $-1(0)$ & $-1(0)$ & $+1(4)$ & $-1(0)$ & $-1(0)$ & $-1(0)$ & $-1(0)$ & 31.25 \\
\hline & 12 & $\begin{array}{l}+1 \\
(8) \\
\end{array}$ & $\begin{array}{c}+1 \\
(40) \\
\end{array}$ & $+1(15)$ & $-1(0)$ & $-1(0)$ & $+1(1.5)$ & $-1(0)$ & $-1(0)$ & $-1(0)$ & 0 \\
\hline & 13 & $-1(4)$ & $\begin{array}{c}+1 \\
(40)\end{array}$ & $+1(15)$ & $+1(4)$ & $-1(0)$ & $-1(0)$ & $+1(1.5)$ & $-1(0)$ & $-1(0)$ & 0 \\
\hline & 14 & $\begin{array}{l}+1 \\
(8) \\
\end{array}$ & $\begin{array}{c}-1 \\
(20)\end{array}$ & $+1(15)$ & $+1(4)$ & $+1(4)$ & $-1(0)$ & $-1(0)$ & $+1(0.5)$ & $-1(0)$ & 0 \\
\hline & 15 & $\begin{array}{l}+1 \\
(8) \\
\end{array}$ & $\begin{array}{c}+1 \\
(40) \\
\end{array}$ & $-1(0)$ & $+1(4)$ & $+1(4)$ & $+1(1.5)$ & $-1(0)$ & $-1(0)$ & $+1(4)$ & 27.78 \\
\hline & 16 & $-1(4)$ & $\begin{array}{c}+1 \\
(40)\end{array}$ & $+1(15)$ & $-1(0)$ & $+1(4)$ & $+1(1.5)$ & $+1(1.5)$ & $-1(0)$ & $-1(0)$ & 0 \\
\hline
\end{tabular}




\section{Generating $1^{\text {st }}$ Order Model}

The model created from the analysis of Plackett-Burman experimental design [12] using multiple regression analysis is based on the $1^{\text {st }}$ order-model:

$$
\boldsymbol{Y}=\boldsymbol{\beta}_{0}+\sum \boldsymbol{\beta}_{i} \boldsymbol{X}_{i}
$$

Where $Y$ is the predicted response, $\beta_{0}$ model constant, $\beta_{i}$ variables linear coefficient.

\section{E. Box-Behnken}

Response surface using Box-Behnken experimental design, modeling and analysis were carried out using the Microsoft Excel 2000 and Essential Exp., Version 2.205 software. Box-Behnken experimental design was used to optimize three variables represented at three levels (high, medium and low) which were denoted by $+1,0$ and -1 respectively. The variables were $\mathrm{pH}\left(\mathrm{X}_{1}\right)$ 8, 4 and 6, Meat extract $\left(\mathrm{X}_{2}\right)$ 4, 2 and $3 \mathrm{~g} / \mathrm{L}$ and Temperature $\left(\mathrm{X}_{3}\right)$ 40,20 and $30^{\circ} \mathrm{C}$. Fifteen experiments were conducted as in Table 6.

\section{F. Multiple Regression Analysis of Box-Behnken Experiments}

The phenol degradation results obtained from the different Box-Behanken experiments were analyzed by multiple regression analysis using Microsoft Excel 2000 and Essential Exp., version 2.205 software.

\section{G. $2^{\text {nd }}$ Order Model}

The created model was applied using the coefficient result of each variable. For the three variables this equation was used:

$Y=\beta_{0}+\beta_{1} X_{1}+\beta_{2} X_{2}+\beta_{3} X_{3}+\beta_{12} X_{1} X_{2}+\beta_{13} X_{1} X_{3}+\beta_{23} X_{2} X_{3}+\beta_{11} X_{1}^{2}+\beta_{22} X_{2}^{2}+\beta_{33} X_{3}^{2}$

$X_{1}, X_{2}$ and $X_{3}$ represent independent variables, $\beta_{1}, \beta_{2}$, and $\beta_{3}$ are liner coefficients, $\beta_{12}, \beta_{13}$ and $\beta_{23}$ are cross product coefficients and $\beta_{11}, \beta_{22}$ and $\beta_{33}$ are the quadratic coefficients.

The various response surface and counter plots for each two variables and their related response (the phenol degradation rate) were performed using Microsoft Excel 2000 and Essential Exp., Version 2.205 software.

\section{H. Microsoft Excel Solver Optimization}

The value of each $\mathrm{pH}\left(\mathrm{X}_{1}\right)$, Meat extract $\left(\mathrm{X}_{2}\right)$ and Temperature $\left(\mathrm{X}_{3}\right)$ was further optimized to calculate the best $Y$ (degradation rate) value using Microsoft Excel 2002 solver. The experiments for calculated optimum $\mathrm{pH}\left(\mathrm{X}_{1}\right)$, Meat extract $\left(\mathrm{X}_{2}\right)$ and Temperature $\left(\mathrm{X}_{3}\right)$ were then conducted.

\section{Determination of the $2^{\text {nd }}$ Order Model Accuracy}

To prove the accuracy of the model, the \% accuracy was calculated from the following formula:

$$
\text { Accuracy of the model }=\left[Y_{\text {Experiment }} / Y_{\text {Calculated }}\right] \times 100
$$




\section{RESULTS}

\subsection{Phenol Degradation Rate With or Without Media Constituents}

The preliminary experiments for phenol degradation in the presence or absence of the media constituents indicated that the microbe could degrade phenol in absence of all of the media constituents. The presence of the media constituents appears to hinder the phenol degradation process while the absence of them give degradation rate of $13.6 \mathrm{mg} / \mathrm{L} / \mathrm{hr}$.

\subsection{Statistical Analysis of Plackett-Burman Experiments}

The experimental design using Plackett-Burman method was produced using +1 and -1 value for each variable as in Table 2 where 16 experiments have been conducted and the results are summarized as phenol degradation rate $(\mathrm{mg} / \mathrm{L} / \mathrm{hr})$ as in Table 2 . The variations in the results prove the importance of using experimental design in the media optimization. For each variable, the responses mean of the experiments with high value $[+1]$ have been calculated using the following formula $\left(\sum+1\right) / \mathrm{n}_{(+1)}$, while the responses mean of the experiments with the low value [-1] have been calculated using the following formula $\left(\sum-1\right) / \mathrm{n}_{(-1)}$. The main effect of the responses for each variable has been calculated from the following formula: Main effect $=\sum(+1) / \mathrm{n}_{(+1)}-\sum(-1) / \mathrm{n}_{(-1)}$. The different main effect of the different variables were calculated and summarized in Fig. 1 and Table 3.

According to the main effect analysis, $\mathrm{pH}$, temperature, yeast extract, meat extract and trace elements give positive effect on the phenol degradation rate while glucose, $\mathrm{NH}_{4} \mathrm{NO}_{3}$, $\mathrm{K}$-salt, Mg-salt give negative effect. The nine variables were analyzed using linear multiple regression analysis method and the \% coefficient level were calculated from the $P$ value and summarized in Table 4 . The analysis of variance using ANOVA test was generated and summarized in Table 5 which gives $P=0.0040$. This indicates that there is a statistically significant relationship between the variables at $99 \%$ confidence level.

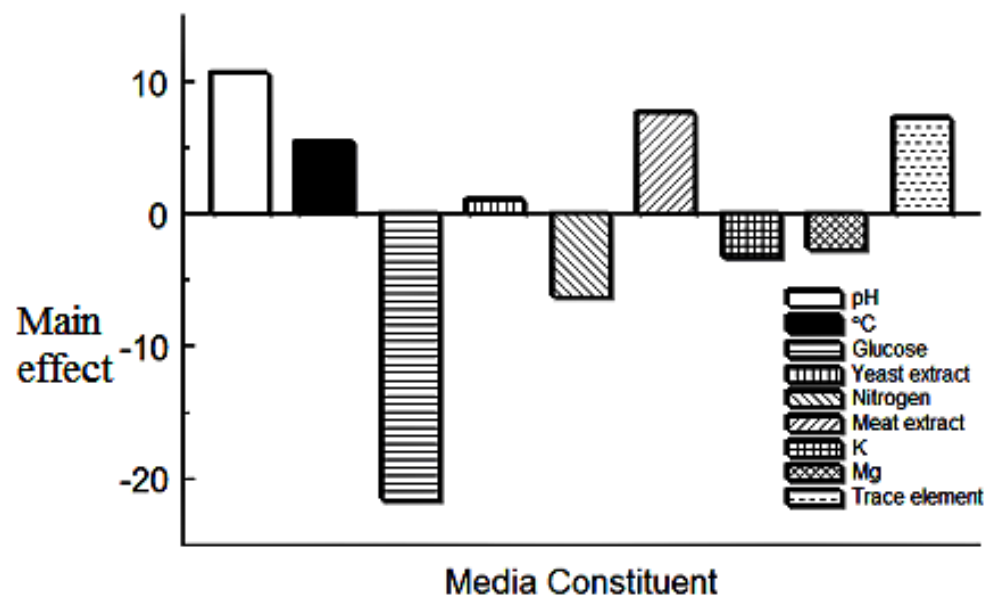

Fig. 1: Effect of environmental and media composition on phenol degradation rate using immobilized Acinetobacter sp. culture. 
Table 3: Main effect.

\begin{tabular}{|c|c|c|c|c|c|}
\hline \multirow{2}{*}{ Code } & \multirow{2}{*}{ Variable } & \multicolumn{2}{|c|}{ Values } & \multirow{2}{*}{ Unit } & \multirow{2}{*}{$\begin{array}{c}\text { Main effect } \\
\sum(+1) / \mathrm{n}_{(+1)}-\sum(-1) / \mathrm{n}_{(-1)}\end{array}$} \\
\hline & & $\left(\sum+1\right) / n_{(+1)}$ & $\left(\sum-1\right) / \mathrm{n}_{(-1)}$ & & \\
\hline $\mathrm{A}$ & $\mathrm{pH}(4 / 8)$ & 16.08 & 5.5424 & & 10.5375 \\
\hline B & Temperature (20/40) & 13.5175 & 8.105 & ${ }^{\circ} \mathrm{C}$ & 5.4125 \\
\hline $\mathrm{C}$ & Glucose (0/15) & 0 & 21.6225 & $\mathrm{~g} / 1$ & -21.6225 \\
\hline $\mathrm{D}$ & Yeast Extract (0/4) & 11.2975 & 10.325 & $\mathrm{~g} / 1$ & 0.9725 \\
\hline $\mathrm{E}$ & Meat Extract (0/4) & 14.595 & 7.0275 & $\mathrm{~g} / 1$ & 7.5675 \\
\hline $\mathrm{F}$ & $\mathrm{NH}_{4} \mathrm{NO}_{3}(0 / 1.5)$ & 7.65875 & 13.96375 & $\mathrm{~g} / 1$ & -6.305 \\
\hline $\bar{G}$ & K-Salt $(0 / 0.5)$ & 9.17 & 12.4525 & $\mathrm{~g} / 1$ & -3.2825 \\
\hline $\mathrm{H}$ & Mg-Salt (0/0.5) & 9.44875 & 12.17 & $\mathrm{~g} / 1$ & -2.725 \\
\hline $\mathrm{I}$ & Trace element $(0 / 4)$ & 14.4062 & 7.216 & $\mathrm{~mL} / 100 \mathrm{~mL}$ & 7.19 \\
\hline
\end{tabular}

Table 4: Linear multiple regression analysis of Plackett-Burman experiments.

\begin{tabular}{|l|l|c|l|c|c|}
\hline \multicolumn{1}{|c|}{ Variables } & \multicolumn{1}{|c|}{ Coefficient } & Standard Error & \multicolumn{1}{c|}{ T Statistic } & P-Value & $\begin{array}{c}\text { Confidence } \\
\text { level \% }\end{array}$ \\
\hline Intercept & 10.8112 & 1.16063 & 9.31496 & 0.0001 & 99.99 \\
\hline Temperature & 2.98734 & 1.41294 & 2.11427 & 0.0789 & 92.11 \\
\hline Glucose & -8.77488 & 1.54846 & -5.66683 & 0.0013 & 99.87 \\
\hline k-salt & -0.0576222 & 1.54846 & -0.0372125 & 0.9715 & 2.85 \\
\hline Meat extract & 0.969583 & 1.51081 & 0.641766 & 0.5447 & 45.53 \\
\hline Mg-salt & -0.563177 & 1.41294 & -0.398585 & 0.7040 & 29.6 \\
\hline NH ${ }_{4} \mathrm{NO}_{3}$ & -1.71674 & 1.52635 & -1.12473 & 0.3037 & 69.63 \\
\hline pH & 2.89627 & 1.46897 & 1.97163 & 0.0961 & 90.39 \\
\hline Trace element & 2.5629 & 1.46897 & 1.74468 & 0.1317 & 86.83 \\
\hline Yeast extract & 0.094239 & 1.52635 & 0.0617413 & 0.9528 & 4.72 \\
\hline
\end{tabular}

Table 5: ANOVA test of Plackett-Burman experiments.

\begin{tabular}{|c|c|c|c|l|c|}
\hline \multicolumn{7}{|c|}{ Analysis of Variance } \\
\hline Source & Sum of Squares & Df & Mean Square & F-Ratio & P-Value \\
\hline Model & 2198.62 & 9 & 244.291 & 11.33 & 0.0040 \\
\hline Residual & 129.319 & 6 & 21.5531 & & \\
\hline $\begin{array}{c}\text { Total } \\
\text { (Corr.) }\end{array}$ & 2327.94 & 15 & & & \\
\hline
\end{tabular}

$R$-squared $=94.4449$ percent

$R$-squared (adjusted for d.f.) $=86.1123$ percent

Standard Error of Est. $=4.64253$

Mean absolute error $=2.36908$ 
The $R$-squared statistic indicates that the model as fitted explains $94.4449 \%$ of the variability in the degradation rate. The adjusted $R$-squared statistic is $86.1123 \%$. The standard error of the estimate shows the standard deviation of the residuals to be 4.64253 . The mean absolute error of 2.36908 is the average value of the residuals.

The multiple linear regression model of Plackett-Burman screening method describes the relationship between the phenol degradation rate and 9 independent variables as indicated in Table 3 and 4 . The equation of the fitted model is:

$Y_{\text {Degradation rate }}=10.8112-8.77488 *$ Glucose $-0.0576222 * \mathrm{~K}$-Salt $+0.969583 *$ Meat extract $-0.563177 * \mathrm{Mg}$-Salt $-1.71674 * \mathrm{NH}_{4} \mathrm{NO}_{3}+2.89627 * \mathrm{pH}+2.98734 *$ Temperature $+2.5629 *$ Trace elements $+0.094239 *$ Yeast extract

From the statistical analysis, Glucose, Temperature and $\mathrm{pH}$ significantly effect the phenol degradation rate while they have confidence level $>90 \%$. The trace elements are considered as being effective [17], whereas $\mathrm{NH}_{4} \mathrm{NO}_{3}$ which give $69.63 \%$ confidence level might be affected by the presence of other media constituents containing nitrogen like meat extract.

\subsection{Statistical Analysis of Box-Behnken Experiments}

Based on the $t$-statistic and $P$ values as well as the \% confidence level obtained from Plackett-Burman experiments (Table 3), Temperature and $\mathrm{pH}$ have positive effect and being statistically significant. They were selected for further optimization.

Glucose which has a negative effect and statistically being significant in phenol degradation has been omitted from the media where it gives the optimum degradation rate when it equals to $0 \mathrm{mg} / \mathrm{L} / \mathrm{hr}$. $\mathrm{NH}_{4} \mathrm{NO}_{3}$ is omitted too while it has \% confidence level less than $70 \%$, even it is so close to $70 \%$ (the minimum accepted limit) [17]. Trace elements were not used based on its performance in experiment 2 and 11. To get the optimum conditions in Box-Behnken, variables were used with the same amounts which give maximum phenol degradation rates according to Plackett-Burman experiment no. 11 (Table 2). Based on experiment no. 11 the media constituents which have 0 amount were omitted. These constituents represent glucose, yeast extract, $\mathrm{NH}_{4} \mathrm{NO}_{3}, \mathrm{~K}$-salt, $\mathrm{Mg}$-salt and trace elements (Table 2). Meat extract, which contains different nutrients could substitute these constituents as shown in experiment no. 11 (Table 2). $\mathrm{pH}\left(\mathrm{X}_{1}\right)$ was used in three level 8, 6, 4; Meat extract $\left(\mathrm{X}_{2}\right) 4,2,0 \mathrm{~g} / \mathrm{L}$ and Temperature $\left(\mathrm{X}_{3}\right) 40,30,20{ }^{\circ} \mathrm{C}$. The BoxBehnken was created using 15 experiments and the phenol degradation rate was determined and summarized in Table 6. 
Table 6: Box-Behnken experiments.

\begin{tabular}{|c|c|c|c|l|}
\hline $\begin{array}{c}\text { Experiment } \\
\text { No. }\end{array}$ & $\begin{array}{c}\mathrm{pH} \\
\mathrm{X}_{1}\end{array}$ & $\begin{array}{c}\text { Meat } \\
\text { Extract } \\
\mathrm{X}_{2}\end{array}$ & $\begin{array}{c}{ }^{\circ} \mathrm{C} \\
\mathrm{X}_{3}\end{array}$ & $\begin{array}{c}\text { Phenol } \\
\text { degradation } \\
\text { rates } \mathrm{mg} / \mathrm{L} / \mathrm{hr}\end{array}$ \\
\hline 1 & $6(0)$ & $0(-1)$ & $40(1)$ & 25 \\
\hline 2 & $6(0)$ & $2(0)$ & $30(0)$ & 35.7 \\
\hline 3 & $6(0)$ & $4(1)$ & $40(1)$ & 22.73 \\
\hline 4 & $4(-1)$ & $0(-1)$ & $30(0)$ & 15.63 \\
\hline 5 & $6(0)$ & $2(0)$ & $30(0)$ & 35.7 \\
\hline 6 & $6(0)$ & $0(-1)$ & $20(-1)$ & 25 \\
\hline 7 & $4(-1)$ & $2(0)$ & $40(1)$ & 25 \\
\hline 8 & $4(-1)$ & $2(0)$ & $20(-1)$ & 17.86 \\
\hline 9 & $8(1)$ & $2(0)$ & $40(1)$ & 22.81 \\
\hline 10 & $4(-1)$ & $4(1)$ & $30(0)$ & 17.86 \\
\hline 11 & $8(1)$ & $4(1)$ & $30(0)$ & 27.78 \\
\hline 12 & $8(1)$ & $2(0)$ & $20(-1)$ & 31.25 \\
\hline 13 & $6(0)$ & $2(0)$ & $30(0)$ & 35.7 \\
\hline 14 & $6(0)$ & $4(1)$ & $20(-1)$ & 25 \\
\hline 15 & $8(1)$ & $0(-1)$ & $30(0)$ & 35.7 \\
\hline & & & & \\
\hline
\end{tabular}

$Y=\beta_{0}+\beta_{1} X_{1}+\beta_{2} X_{2}+\beta_{3} X_{3}+\beta_{12} X_{1} X_{2}+\beta_{13} X_{1} X_{3}+\beta_{23} X_{2} X_{3}+\beta_{11} X_{I}^{2}+\beta_{22} X_{2}{ }^{2}+\beta_{33} X_{3}^{2}$
Where $X_{1}=\mathrm{pH}, \mathrm{X}_{2}=$ Meat extract and $\mathrm{X}_{3}={ }^{\circ} \mathrm{C}$ 
Table 7: Linear multiple regression analysis of Box-Behnken experiments.

\begin{tabular}{|c|c|c|c|c|c|}
\hline Variables & Coefficient & $\begin{array}{l}\text { Standard } \\
\text { Error }\end{array}$ & T Statistic & P-Value & $\begin{array}{c}\text { Confidence level } \\
\%\end{array}$ \\
\hline Intercept & 35.7 & 1.74571 & 20.4501 & 0.0000 & \\
\hline $\mathrm{X} 1$ & 5.14875 & 1.06903 & 4.8163 & 0.0048 & 99.52 \\
\hline $\mathrm{X} 1 \mathrm{X} 1$ & -5.83 & 1.57356 & -3.70497 & 0.0139 & 98.61 \\
\hline $\mathrm{X} 1 \mathrm{X} 2$ & -2.5375 & 1.51183 & -1.67843 & 0.1541 & 84.60 \\
\hline X1X3 & -3.895 & 1.51183 & -2.57635 & 0.0497 & 95.03 \\
\hline $\mathrm{X} 2$ & -0.995 & 1.06903 & -0.930754 & 0.3947 & 60.56 \\
\hline $\mathrm{X} 2 \mathrm{X} 2$ & -5.6275 & 1.57356 & -3.57628 & 0.0159 & 98.40 \\
\hline $\mathrm{X} 2 \mathrm{X} 3$ & -0.5675 & 1.51183 & -0.375373 & 0.7228 & 27.71 \\
\hline $\mathrm{X} 3$ & -0.44625 & 1.06903 & -0.417436 & 0.6937 & 30.61 \\
\hline X3X3 & -5.64 & 1.57356 & -3.58422 & 0.0158 & 98.42 \\
\hline
\end{tabular}

Table 8: ANOVA test of Box-Behnken experiments.

\begin{tabular}{|l|c|c|c|c|c|}
\hline \multicolumn{7}{|c|}{ Analysis of Variance } \\
\hline Source & Sum of Squares & Df & Mean Square & F-Ratio & P-Value \\
\hline Model & 621.23 & 9 & 69.03 & 7.550 & 0.01924 \\
\hline Residual & 45.71 & 5 & 9.143 & & \\
\hline Total (Corr.) & 666.95 & 14 & & & \\
\hline
\end{tabular}

R-squared $=93.1433$ percent

R-squared (adjusted for d.f.) $=80.8011$ percent

Standard Error of Est. $=7.56375$

Mean absolute error $=3.42139$

The analysis of variance used in Box-Behnken experiment (Table 6) was created using ANOVA test as in Table 8 which gives $P=0.01924$. Since the $P$-value in the ANOVA table is less than 0.05 , there is a statistically significant relationship between the variables at the $95 \%$ confidence level. The $R$-squared statistic suggests that the model as fitted explains $93.146 \%$ of the variability in the degradation rate. The adjusted $R$-squared statistic, which is more suitable for comparing models with different numbers of independent variables, is $80.8087 \%$. The standard error of the estimate shows the standard deviation of the residuals to be 3.02366. The mean absolute error of 1.36667 is the average value of the residuals.

The multiple linear regression model of the Box-Behnken analysis experiments describe the relationship between the degradation rate and 3 independent variables as in Table 6 and 7. The equation of the fitted model is: 
$Y_{\text {Degradation rate }}=35.7-5.83 * p H^{*} p H-2.5375^{*} p H *$ Meat extract $-3.895 * p H$

*Temperature - 5.6275* Meat extract* Meat extract $-0.5675^{*}$ Meat extract *

Temperature $-5.64 *$ Temperature $*$ Temperature $-0.995^{*}$ Meat extract $+5.14875^{*} p H$ $0.44625 *$ Temperature

From the statistical analysis, it can be concluded that $\mathrm{pH}$ is the most significant variable affecting the phenol degradation rate. The best level of the three variable as obtained from the maximum point of polynomial model were estimated using the solver function of Microsoft Excel 2000 tool and found to be $\mathrm{pH}=7.12$, Meat extract $=1.6 \mathrm{~g} / \mathrm{L}$, and Temperature $=27.77^{\circ} \mathrm{C}$, with a prediction calculated degradation rate equal to 37.30 $\mathrm{mg} / \mathrm{L} / \mathrm{hr}$. The various response surface and counter plots for each two variables and the response (the phenol degradation rate) were drawn using Excel 2000 and Essential Exp. Version 2.205 software as shown in Fig. 2 to 7.

The data obtained from the response surface, counter plots and Table 7, show that $\mathrm{pH}$ and ${ }^{\circ} \mathrm{C}$ are the most significant variables affecting on the phenol degradation rate. The interaction between $\mathrm{pH}$ and ${ }^{\circ} \mathrm{C}$ is significant [16] with confidence level \% equal to 95.03 , and between $\mathrm{pH}$ and meat extract is effective [17] with confidence level \% equal to 84.60 . On the other hand the interaction between meat extract and temperature is insignificant with confidence level \% equal to 27.71 . This also clearly proves that $\mathrm{pH}$ is the most effective variable.. Meat extract has a limit in improving the degradation rate but plays an essential role in stabilizing the media composition. The role of meat extract must be subjected to further investigation concerning its composition.

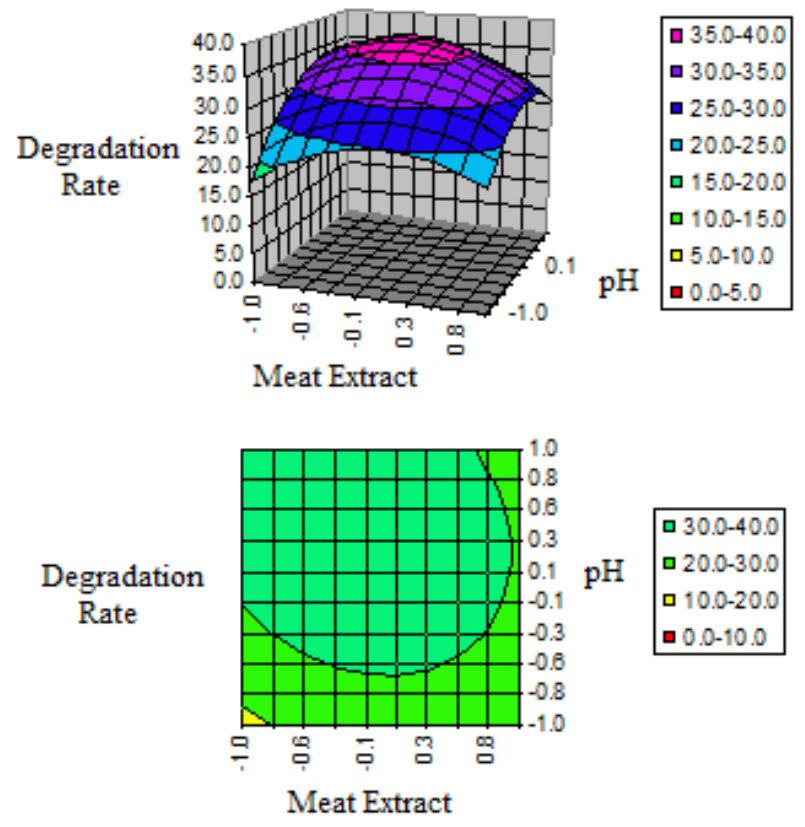

Fig. 2 and 3: The response surfaces plot and corresponding contour plot showing the effects of Meat extract (above) and $\mathrm{pH}$ (below) on phenol degradation rate. 
The shape of response surface and counter plots (Fig. 2 and 3) show high interaction between $\mathrm{pH}$ and meat extract. The results obtained from Fig. 4 and 5 concerning the interaction between $\mathrm{pH}$ and temperature show high interaction. In case of Fig. 6 and 7 the interaction between meat extract and temperature gives only small interaction. The results obtained from Fig. 2 to 7 agree with that in Table 7.
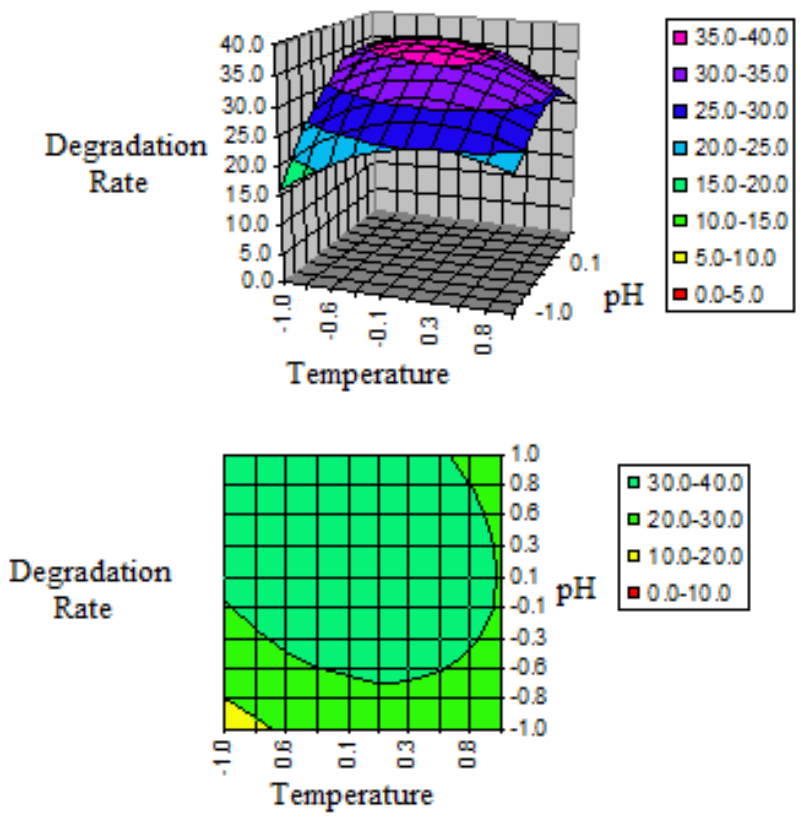

Fig. 4 and 5: The response surfaces plot and corresponding contour plot showing the effects of Temperature (above) and $\mathrm{pH}$ (below) on phenol degradation rate.

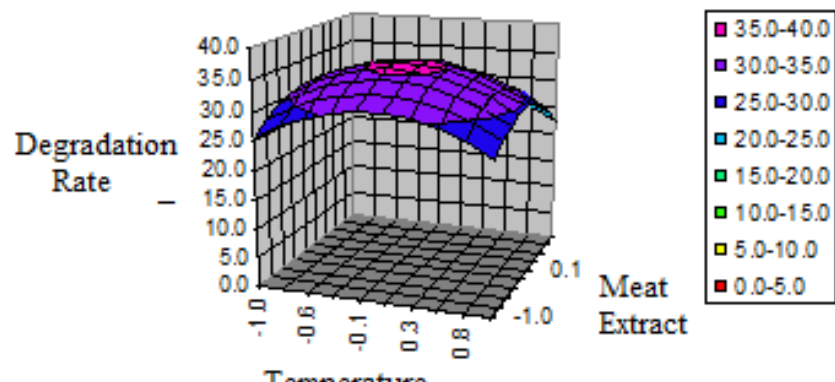

Temperature

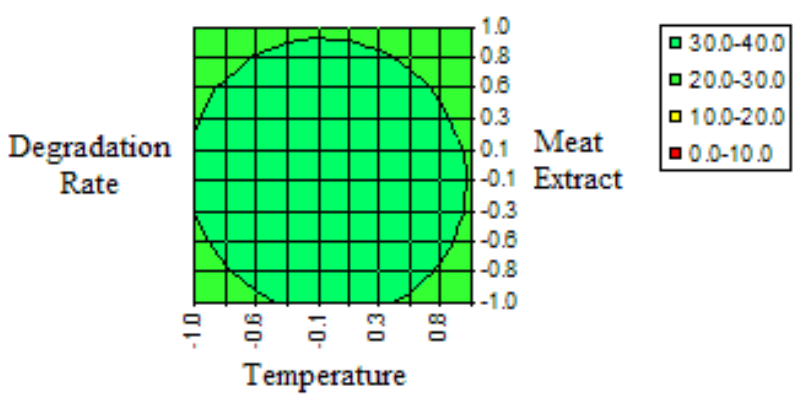

Fig. 6 and 7: The response surfaces plot and corresponding contour plot showing the effects of Meat extract (above) and Temperature (below) on the phenol degradation rate. 


\subsection{Confirming Accuracy of Model}

The $Y$ value which has been optimized from the model was calculated using Microsoft Excel found to be 37.30 at $\mathrm{pH}=7.12$, meat extract $=1.6$ and temperature $=27.77^{\circ} \mathrm{C}$. The in vivo experiment shows that $Y$ value of $38.45 \mathrm{mg} / \mathrm{L} / \mathrm{hr}$. The calculated model accuracy was $103.08 \%$.

\section{DISCUSSION}

Degradation of chemical compounds is an important microbial criterion. Phenol, which is a toxic natural or synthetic compound, can be degraded to non-toxic by different microbes [1-11]. Phenol can be degraded by aerobic and anaerobic bacteria [18-20]. Phenol can be a growth inhibitor to microorganisms at elevated concentration [21]. This criteria lead to a conclusion that each strain, which is able to degrade phenol should be treated, analyzed and optimized as a single case.

Optimization of the media constituents as well as the other environmental variables like $\mathrm{pH}$, temperature, etc., using well established experimental design can map the conditions affecting on the different processes concerning media optimization [21-25]. While biological system is complex and can be affected by unknown factors, using Plackett-Burman analysis could detect the weak and the strong points in the process under investigation [12]. Microbes have unique criterion and they are usually prefer and utilize simple carbon source such as glucose as opposed to complex carbon sources. In this study the presence of glucose in the media omit any chance that the bacterial strain start to degrade phenol as shown in Table 1 and experiments no. 3, 4, 9, 12, 13, 14 and 16 as (Table 2). The results from Table 1 lead the use of 0 amount as a low level [-1] to investigate which of the media constituents could be removed. The absence of glucose forces the microbe to degrade the phenol as shown in Table 2. Glucose as an example shows a significant effect on the degradation rate. Meanwhile, the main effect analysis as in Table 3 and Fig. 1 show that this to be a negative effect. Using glucose in $0 \mathrm{~g} / \mathrm{L}$ gave the best result as indicated in Table 2. For these reasons, even glucose has the highest $\%$ confidence level, it is not considered. The main effect as shown in Table 3 and Fig. 1 gave clear view about each variable's mode of action. Main effect classified the variables to positive and negative, which support the analysis of variables and highlight in which direction the optimization should be conducted.

This study does not follow the usual way of optimization. Using the usual way of optimization will lead to select glucose, temperature and $\mathrm{pH}$ for further optimization (e.g Box-Behnken method). Temperature and $\mathrm{pH}$ are significant variables with $\%$ confidence level equal to 92.11 and 90.39 , respectively and have been selected for optimizations. Based on the results obtained from experiment no. 11 using Plackett-Burman design beside glucose; yeast extract, $\mathrm{NH}_{4} \mathrm{NO}_{3}, \mathrm{~K}$-salt, $\mathrm{Mg}$-salt and trace elements have been omitted while they gave the best degradation rate when they were at 0 amount as in Table 2. In experiment no. 2 and 11, meat extract was in its high value $[+1](4 \mathrm{~g} / \mathrm{L})$. Comparing the media constituents in experiment no 2 and 11 lead to a conclusion that meat extract perfectly could substitute the other factors used in 0 amount. However, this fact was not detected by statistical analysis. 
Box-Behnken experimental design was performed using 15 experiments (Table 6), and four experiments give phenol degradation rate of $35.7 \mathrm{mg} / \mathrm{L} / \mathrm{hr}$, which indicate a possibility for further optimization. Using the solver tool in Microsoft Excel 2002 to optimize the model created from Box-Behnken the calculated degradation rate was 37.30 $\mathrm{mg} / \mathrm{L} / \mathrm{hr}$ in the optimum calculating condition. To prove the efficiency of using the Microsoft Excel solver the in vivo experiments were conducted. The degradation rate for the in vivo was $38.45 \mathrm{mg} / \mathrm{L} / \mathrm{hr}$.

Using direct phenol degradation (without media) gives $13.6 \mathrm{mg} / \mathrm{L} / \mathrm{hr}$. By using Plackett-Burman the maximum degradation rate was $31.25 \mathrm{mg} / \mathrm{L} / \mathrm{hr}$ which represent 2.3 time increase than that at Table 1. Using Box-Behnken design the maximum degradation rate was 35.7 which is 2.71 fold increase than that without media and $14.24 \%$ more than Plackett-Burman. Using Excel solver optimization gives $37.30 \mathrm{mg} / \mathrm{l} / \mathrm{hr}$ degradation rate mathematically and $38.45 \mathrm{mg} / \mathrm{L} / \mathrm{hr}$ degradation rate experimentally. The in vivo experiment shows $103.08 \%$ model accuracy which indicates the advantage of the experimental design for optimization. Applying the conditions which were optimized using Excel solver for in vivo experiment result in degradation rate equal $38.45 \mathrm{mg} / \mathrm{L} / \mathrm{hr}$ which is 2.92 fold increase than that without media and which is $23.04 \%$ more than Plackett-Burman and 7.70\% more than Box-Behnken.

Different strategies have been developed for controlling phenol and preventing it from causing harmful effect on Nature [8-10]. Using immobilized technique has also been described [25]. The main problems in different strategies are the phenol degradation optimization. Most of the studies describe analysis of one variable at a time, which usually did not give the maximum expected optimization and is time consuming. Media optimization using experimental design proved to be more efficient [26]. As what has been done in this study many authors described using different nutrients to improve the growth of microbial strains which will be finally improve phenol degradation rate under some controlling conditions. An example is the glucose has been used to overcome the inhibitory effect of phenol on microbial growth as described by Mamma et al. [27]. In this study. glucose completely inhibit the phenol degradation which prove our concept that each microbe should be treated as a special case.

Experimental design using Plackett-Burman, Box-Behnken and Excel solver lead to subsequent improvements in phenol degradation rate. Logical analysis of the data leads to a better understanding of the roles of variables and investigation as to which one should be used. Statistical analysis help a lot in understanding the behavior of each variable but variables which gave the same results should be subjected to logical analysis with the aim to obtain the correct choice.

We should highlight that the phenol used in this study did not represent reality while in fact phenol was usually present as a contaminant with other wastes like olive oil. This fact should be taken into consideration in any future studies aimed. While Plackett-Burman and Box-Behnken are well-established tools for experimental design, we recommend using our strategy for the best use of both of them. 


\section{REFERENCES}

[1] K. A. Khan, M. T. Suidan, and W. H. Gross, "Anaerobic carbon filter for the treatment of phenol bearing waste water". J. Water Pollut. Control Fed., vol. 53 pp. 1519-1532, 1981.

[2] J. A. Field, and G. Lettinga, "Treatment and detoxification of aqueous spruce bark extracts by Aspergillus niger”. Water Science and Technology., vol. 24 pp.127-137, 1991.

[3] R. Borja, A. Martin, R. Maestro, M. Luque, and M. M. Duran, "Enhancement of the anaerobic digestion of wine distillery wastewater by the removal of phenolic inhibitors". Bioresource Technology., vol. 45 pp. 99-104, 1993.

[4] D. Brand, A. Pandey, S. Roussos, and C. R. Soccol, "Biological detoxification of coffee husk by filamentous fungi using a solid state fermentation system". Enzyme and Microbial Technology., vol. 27 pp. 127-133, 2000.

[5] L. Lesage-Meessen, D. Navarro, S. Maunier, J-C. Sigoillot, J. Lorquin, M. Delattre, J-1. Simon, M Asther, and M. Labat, "Simple phenolic content in olive oil residues as a function of extraction system”. Food Chemistry., vol. 75 pp. 501-507, 2001.

[6] M. Minhalma, and M. N. De Pinho, "Tannic-membrane interactions on ultrafiltration of cork processing wastewater". Separation and Purification Technology., vol. 22 pp. 479-488, 2001.

[7] G. Aggelis, C. Ehaliotis, F. Nerud, I. Stoychev, G. Lyberatos, and G. I. Zervakis, "Evaluation of white-rot fungi for detoxification and decololorization of effluents from green olive debittering process". Applied Microbiology and Biotechnology., vol. 2 pp. 353-360, 2002.

[8] G. R. Chaudhry, and S. Chapalamadugu, "Biodegradation of halogenated organic compounds". Microbial. Rev., vol. 55(1) pp. 59-79, 1991.

[9] S. M. Armstrong, and T. R. Patel, "Microbial degradation of phloroglucinol and other polyphenolic compounds". J. Basic. Microbiol., vol. 34(2) pp. 123-135, 1994.

[10] J. P. Kaiser, Y. Feng, and J. M. Bollag, "Microbial metabolism of pyridine, quinoline, acridine, and their derivatives under aerobic and an anaerobic conditions". Microbiol Rev., vol. 60(3) pp. 483-498, 1996.

[11] I. P. Solyanikova, and L. A.Golovleva, "Bacterial degradation of chlorophenols: pathways, biochemica, and genetic aspects". J. Environ. Sci. Health B., vol. 39(3) pp. 333-351, 2004.

[12] P. Plackett, and J. P. Burman, "The design of optimum multifactorial experiments Biometrika”. vol. 37:305-325, 1946.

[13] Box, G. E. P. and Behnken, D. W. "Some new three levels designs for the study of quantitative variables".. Technometrics., vol. 2 pp. 455-457, 1960.

[14] H. G. Schlegel, H. Kaltwasser, and G. Gottschalk, „Eine submersverfahren zur kulture wasserstoffoxydierender Bakterien: Wachstums physiologische untersuchungen“. Arch. Mikrobiol., vol. 38 pp. 209-222, 1961.

[15] Y. I. Korenman, T. A. Kuchmenko, and S. A. Karavaev, "ExtractionSpectrophotometric determination of phenol using a reaction with 4-Amino antipyrine in the two phase poly (ethylene glycol)-Ammonium sulphate water system”. J. Analyt. Chemistry., vol. 53(3) pp. 291-296, 1998.

[16] Y. R. Abdel-Fattah and Z. A. Olama "L-asparaginase production by Pseudomonas aeruginosa in solid-state culture: evaluation and optimization of culture conditions using factorial designs”. Process Biotechnol., vol. 38 pp. 115-122, 2002. 
[17] R. A. Stowe, and R.P. Mayer, "Efficient screening of process variables". Ind Eng. Chem., vol. 58 pp. 36-40, 1966.

[18] H. H. P. Fang, D. W. Liang, T. Zhang and Y. Liu "Anaerobic treatment of phenol in wastewater under thermophilic condition". Water Res. vol. 40 pp. 427-434, 2006

[19] D. R. Lovley and D. J. Lonergan "Anaerobic oxidation of toluene, phenol, and pcresol by the disssimilatory iron-reducing organism". GS-15, Appl. Environ.Microb. vol. 56(6) pp. 1858-1864, 1990

[20] M. M. Broholm and E. Arvin "Biodegradation of phenols in a sandstone aquifer under aerobic conditions and mixed nitrate and iron reducing conditions". J. Contam. Hydrol. vol. 44 pp. 239-273, 2000

[21] G. A. Hill and C. W. Robinson "Substrate inhibition kinetics: phenol degradation by Pseudomonas putida". Biotechnol. Bioeng. vol. 17 pp. 1599-1615, 1975

[22] K. W. Wang, D. M. Tsangaris, B. C and G. A. Baltzis "Lewandowski, Biodegradation of mixed wastes in continuously operated cyclic reactors". Appl Biochem Biotechnol vol. 57-58 pp. 803-815, 1996

[23] J. Shen, Z. X. Lu, X. M. Bie, F. X and X. Q. Lu "Huang, [Media optimization for the novel antimicrobial peptide by Bacillus sp. fmbJ224]". Sheng Wu Gong Cheng Xue Bao, vol. 21 pp. 609-614, 2005

[24] Y. X. Wang, Z. X. Lu and F. X. Lu "[Media optimization for exopolysaccharide by Pholiota squarrosa (Pers. ex Fr.) Quel. AS 5.245 on submerged fermentation]". Sheng Wu Gong Cheng Xue Bao., vol. 20 pp. 414-422, 2004

[25] C. Wang, and Y. Li "Incorporation of granular activated carbon in an immobilized membrane bioreactor for the biodegradation of phenol by Pseudomonas putida". Biotechnol Lett. Vol. 9 pp. 1353-1356, 2007

[26] G. Annadurai, L.Y. Ling and J. F. Lee "Statistical optimization of medium components and growth conditions by response surface methodology to enhance phenol degradation by Pseudomonas putida". J. Hazard Mater., vol. 151 pp. 171178,2008

[27] D. Mamma, E. Kalogeris, N. Papadopoulos, D. G. Hatzinikolaou, P. Christrakopoulos and D. Kekos "Biodegradation of phenol by acclimatized Pseudomonas putida cells using glucose as an added growth substrate'. J. Environ. Sci. Health A. Tox. Hazard. Subst. Environ. Eng. Vol. 39 pp. 2093-2104, 2004 